\title{
Assessment of Landscape Characteristics and Changes in the Khangchendzonga National Park, Sikkim Himalaya, India
}

Sandeep Tambe ${ }^{1 *}$, Krishnamurthy Ramesh ${ }^{2}$ and Gopal S. Rawat ${ }^{2}$

${ }^{1}$ Department of Rural Management and Development, Government of Sikkim, Gram Vikas Bhawan, Gangtok - 737101, Sikkim, India

${ }^{2}$ Wildlife Institute of India, Dehra Dun - 248001, Uttarakhand, India

\begin{abstract}
The Khangchendzonga National Park (KNP) in India forms a part of the eastern Himalaya global biodiversity hotspot. Being the third highest protected area in the world, much of the park is inaccessible and has remained least understood. In this study, Remote Sensing and GIS tools were used to quantify landscape composition, configuration and patterns of changes in vegetation cover. From Landsat ETM+ data, 10 land cover types could be classified with $81 \%$ accuracy, which showed relatively higher coverage of snow, rock and alpine meadows. FRAGSTATS recognized 70790 patches with mean patch size of 1.2 ha. Watershed based approach showed that parts of KNP that had higher landscape heterogeneity, reflected a greater Himalayan character, high elevation gradient, east west orientation and not dominantly sculptured by valley glaciers. Riverine areas were found to be susceptible to glacial lake outburst and flash floods. Also vegetation cover has substantially declined at lower elevations (1000 to $2500 \mathrm{~m}$ ) in the last three decades, particularly in portions not shielded from the villages by buffer forests. The park management needs to evolve innovative co-management models, use the riverine zone carefully, strengthen buffer zone management and prioritize conservation measures in the high impact areas.
\end{abstract}

Keywords: Eastern Himalaya; FRAGSTATS; Conservation management; Spatial analysis; Vegetation mapping; Watershed

\section{Introduction}

Protected areas (PAs) are viewed as cornerstones of biodiversity conservation in most of the countries and there are over 100000 PAs in the world, covering an area of about 18 million $\mathrm{km}^{2}$ [1]. It is, however, necessary for the natural resource ecologists and managers to periodically evaluate the management effectiveness of these protected systems. This requires monitoring of appropriate variables [2]. Many changes can go unnoticed in the absence of well established monitoring protocols and spatially explicit data. Remote sensing technology and associated spatial analysis tools are highly useful in conservation planning [3-5], landscape ecology [6-8] and assessing the impacts of climate change [9]. Multi-spectral and multi-temporal data obtained from remote sensing allows integration of several layers and change detection more quickly and effectively [10]. Spatial analysis tools further help to discern the spatial and functional properties of the

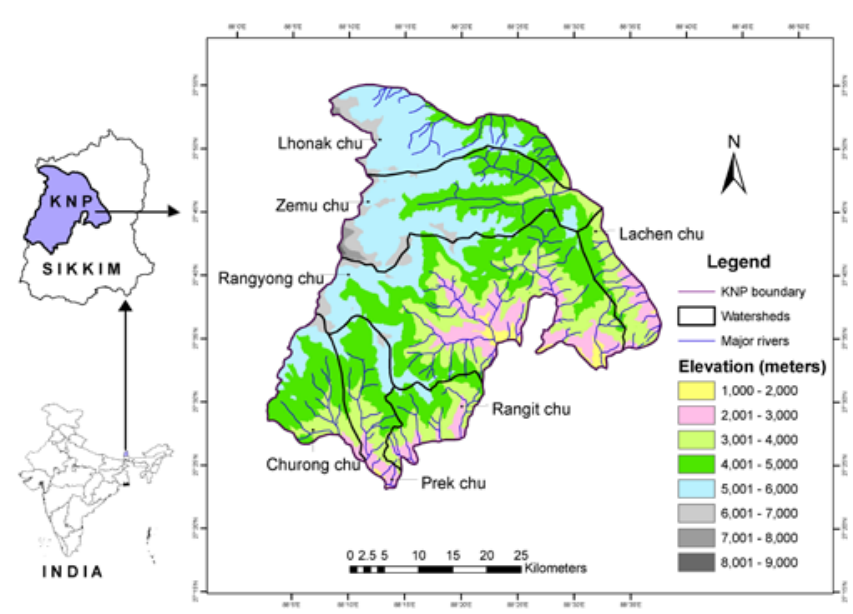

Figure 1: Location and physiography of Khangchendzonga National Park. landscape elements which are influenced by natural and anthropogenic factors. The PA managers need to detect positive and negative changes at a landscape level in order to take appropriate management decisions. These tools are particularly useful for areas located in the Himalaya, where adequate field sampling is often negated by nonnegotiable rugged terrain. Traditionally, conservation management in the Himalayan system revolved around information from natural history records documented by biologists and managers, and by intensive studies resulting into a spatial quantitative data that lacked location details and were restricted to small spatial and temporal scales. Alternately, the major paradigm shift that has been brought about positively by the application of Remote Sensing and GIS is its ability to capture information at fairly larger spatial and temporal scales, and more critically, the information is depicted in spatially explicit form. It facilitates the managers readily to understand location based details for directing appropriate conservation management decisions and efforts.

The Khangchendzonga National Park (KNP) (Figure 1), located in the eastern Himalaya, is the third highest PA in the world and represents a complex mosaic of landscape elements, the most dominating feature being the high alpine and aeolian environments. It harbours varied ecosystems which have been strongly influenced by monsoon climate and to some extent by anthropogenic pressures especially towards the outer fringes. Previous studies using remote sensing in this region were

*Corresponding author: Sandeep Tambe, Department of Rural Management and Development, Government of Sikkim, Gram Vikas Bhawan, Gangtok - 737101, Sikkim, India, Tel: 919474059791; Fax: 913592203852; E-mail: sandeep_tambe@yahoo.com

Received November 10, 2011; Accepted December 28, 2011; Published January 05, 2012

Citation: Sandeep T, Krishnamurthy R, Gopal SR (2012) Assessment of Landscape Characteristics and Changes in the Khangchendzonga National Park, Sikkim Himalaya, India. J Geophys Remote Sensing 1:102. doi:10.4172/2169-0049.1000e102

Copyright: (c) 2012 Sandeep T et al. This is an open-access article distributed under the terms of the Creative Commons Attribution License, which permits unrestricted use, distribution, and reproduction in any medium, provided the original author and source are credited. 
largely limited to broad vegetation classification and phytodiversity characterization [11-13]. In this paper, we present details of landscape composition, configuration and patterns of changes in vegetation cover in three decades based on fine scale remote sensing data and landscape analysis using specialized software. The objectives also include demonstrating a credible model to understand management issues in a large landscape and prioritize conservation action in a biodiversity rich Himalayan state which lacks adequate financial and human resources.

\section{Study Area}

The KNP is located on the western flank of Sikkim (India) adjacent to Nepal, between $27^{\circ} 30^{\prime}$ to $27^{\circ} 55^{\prime} \mathrm{N}$ latitudes and $88^{\circ} 02^{\prime}$ and $88^{\circ}$ $37^{\prime}$ E longitudes, covering an area of $1784 \mathrm{~km} 2$ (Figure 1). It forms a part of the eastern Himalaya that has been recognized as one of the 34 global biodiversity hotspots $[14,15]$. The park is named after Mt. Khangchendzonga $(8586 \mathrm{~m})$, the third highest peak in the world and the highest in India. The annual rainfall varies from less than $150 \mathrm{~cm}$ in the north to more than $300 \mathrm{~cm}$ in the southern parts. The park is known for its steep and rugged terrain [16]. The elevation of KNP varies from about 1220 to $8586 \mathrm{~m}$ within an aerial distance of less than $40 \mathrm{~km}$. About $90 \%$ of the park lies above $3000 \mathrm{~m}, 70 \%$ above $4000 \mathrm{~m}$ which has nine peaks rising above $7000 \mathrm{~m}$. There are a number of small and large glaciers, longest being $26 \mathrm{kms}$ (Zemu glacier). The characteristic geomorphology and glaciated landscape has given rise to more than 73 glacial lakes within the park [17]. The park is divisible into seven major watersheds viz., Churong chu, Prek chu, Rangit chu, Lachen chu, Rangyong chu, Zemu chu, and Lhonak chu (local chu = river).

The sharp altitudinal gradient and complex topography have manifested in diverse vegetation types. As many as 18 distinct forest types and sub-types are discernible within KNP as per the forest classification by Champion and Seth [18]. Maity and Maiti (2007) recorded 1580 species of vascular plants from KNP and surrounding buffer forests which include 11 gymnosperms, 106 species of pteridophytes and 1463 angiosperms. The park is an important habitat for a large number of rare and threatened mammals such as the Himalayan musk deer (Moschus chrysogaster), red panda (Ailurus fulgens), snow leopard (Uncia uncia) and a variety of avifauna. The land use practices in the area include grazing of livestock (yaks, cow-yak crossbreeds, horses and sheep), collection of medicinal and aromatic plants and tourism.

\section{Methods}

\section{Field data collection}

The study area was surveyed during summer and winter seasons in 14 field visits spanning 125 days over a three-year period from 2004 to 2006. A total of 161 ground reference points along with attribute data on location and vegetation characteristics were recorded using a hand-held Garmin Global Positioning System (GPS; 12-channel Etrex summit mode). Winter surveys helped in creating a database of about 200 digital photographs of the landscape which helped during visual interpretation especially of areas under shadow.

\section{Spatial data and image processing}

The Shuttle Radar Topographic Mission (SRTM) produced by NASA originally, has provided high quality digital elevation data (DEMs). The SRTM 90m DEM file (srtm_54_07.zip) was downloaded from the CGIAR-CSI GeoPortal [19]. This file in Geotiff format was processed in Erdas Imagine software (version 8.5). The study area was subset from this image and exported to grid format. In Arcview GIS (version 3.2) the surface option of the spatial analyst extension was used to create contours and to derive aspect and slope maps.
The $30 \mathrm{~m}$ resolution Landsat ETM+ (2000) dataset was downloaded in the Geotiff format from the Global Land Cover Facility (www. landcover.org) through the geoportal http://glcfapp.umiacs.umd.edu. The sub-scene (path/row, 139/041, $5^{\text {th }}$ December, 2000) corresponding to Sikkim was extracted. The input files were unzipped and the layer stack option in the image interpreter module of Erdas was used, and the bands 1 to 5 were selected to create the output multispectral image file. The Landsat-7 ETM+ data was classified in unsupervised (40 classes) mode, and failed to show adequate separability between vegetation classes like oak and conifer, and subalpine thickets and bamboo thickets. Using the classifier module of Erdas an unsupervised maximum likelihood classification of the 5-band (1:5) composite was carried out with 40 classes initially. Isodata clustering algorithm was used, and maximum number of iteration was found to be 10 for the convergence threshold of 0.96 . The resultant 40 classes were checked individually against ground-truth data of landcover types collected in the field along with geographic coordinates. The problems encountered were misclassification of the shadow areas, non-separability of temperate oak and subalpine fir and bamboo thickets merging with krummholz. These uncertainties were addressed by visual interpretation process involving ground truth data, image tone and elevation information. The hybrid approach combining efforts from both unsupervised classification process and visual interpretation resulted in the final 10 broad landcover classes (Figure 2). Separability of the classes and classification accuracy were then assessed. 161 ground truth points were used for assessing the separability of the classes and classification accuracy. The population of the villages was taken from the Census of India [20]

\section{Landscape analysis}

The landscape configuration was analyzed using the spatial pattern analysis software FRAGSTATS (version 3.3) [21]. The grain of the study was the spatial resolution of the satellite image $(28.5 \mathrm{~m})$, while the extent was $1784 \mathrm{~km}^{2}$ (the area of the KNP). Both natural and disturbed vegetation classes were used in the study. Since bamboo thickets occur as a middle storey in oak forests, it was natural to club it with this

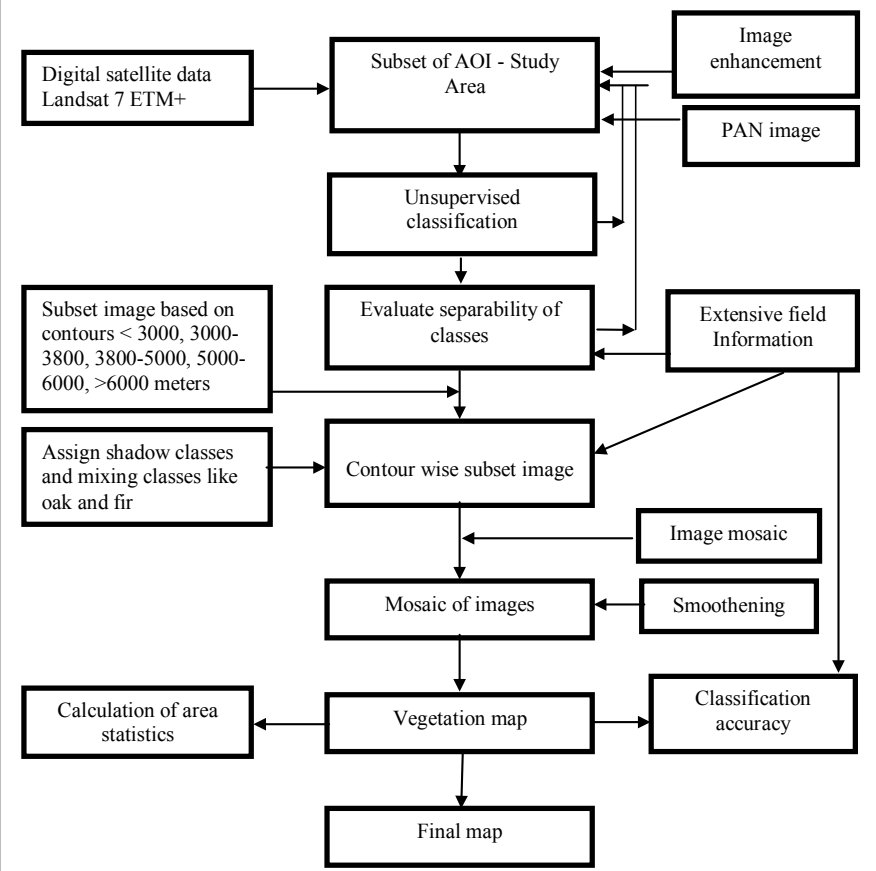

Figure 2: Image processing and vegetation classification of the satellite data. 
Citation: Sandeep T, Krishnamurthy R, Gopal SR (2012) Assessment of Landscape Characteristics and Changes in the Khangchendzonga National Park, Sikkim Himalaya, India. J Geophys Remote Sensing 1:100 . doi:10.4172/2169-0049.1000101[

Page 3 of 8

vegetation class. The results were aggregated thematically at vegetation class level. The landscape characteristics were determined from the patch, class and landscape level metrices generated from the software. Landscape indices, their methods of calculation, symbols and units used are as defined in the FRAGSTATS user manual [21].

The Khangchendzonga massif presides over the physiography of KNP. The seven watersheds or river sub-systems namely the Lhonak, Zemu, Lachen, Rangyong, Rangit, Prek and Churong though located adjacent to one another, show significant variation in physiography and climate (Figure 1). Although the Greater Himalaya generally runs in an east-west direction, the chief ridge of Khangchendzonga range here is aligned in north-south inclination with west-east running transverse spurs. The monsoon winds blowing from the south-easterly direction bring heavy precipitation and are obstructed by successive west-east ridge formations, significantly reducing the precipitation towards the north. The annual rainfall decreases from 2.75 meter in the southeastern part to 0.75 meter in the north with the average being 2.14 meter [22]. While the southern part of KNP (Rangit, Prek and Churong), represents the wet part that is the Outer Himalaya, central part (Zemu, Lachen, Rangyong) represents the transitional inner Himalaya, and the high valley of Lhonak the Tibetan Himalaya [23]. Hence to highlight the unique characteristics of these watersheds, their landscape characteristics were aggregated including composition, shape, configuration and diversity (Table 6, Figure 1).

\section{Temporal change detection}

The georeferenced Landsat time series data of $23^{\text {rd }}$ January, 1977 [24] and $26^{\text {th }}$ December, 2000 [25] were used for temporal change detection. Atmospheric correction was performed with Idrisi Kilimanjaro (v14) using the ATMOSC module. All imagery was corrected using the $\operatorname{Cos}(\mathrm{t})$ model with input parameters reported in the metadata supplied by Landsat [26]. The $30 \mathrm{~m}$ resolution Landsat ETM+ (2000) image was degraded to 60 meters using the utilities option in the image interpreter module of Erdas to match with the Landsat MSS (1977) image. Normalized difference vegetation index (NDVI) has been widely used as an indicator of the presence and condition of green vegetation. The NDVI helps compensate for changing illumination conditions, surface slope, aspect and other extraneous factors. NDVI was calculated for each of the images using the spectral enhancement option, followed by change detection using the utilities option in the image interpreter module of Erdas [27]. The decrease in winter snow and increase in illumination of shadow areas resulted in a positive biasing of the change detection, hence only the negative changes were used.

\begin{tabular}{|l|l|l|l|l|l|l|}
\hline Landcover type & \multicolumn{5}{|c|}{ Extent in KNP } \\
\hline & Greater Himalaya & Trans Himalaya & Total \\
\hline & $\mathrm{km}^{2}$ & $\%$ & $\mathrm{~km}^{2}$ & $\%$ & $\mathrm{~km}^{2}$ & $\%$ \\
\hline Snow & 541.8 & 35.2 & 71.7 & 29.4 & 613.5 & 34.4 \\
\hline Rock & 253.2 & 16.4 & 77.9 & 31.9 & 331.1 & 18.6 \\
\hline Alpine meadow & 199.8 & 13.0 & 62.5 & 25.6 & 262.3 & 14.7 \\
\hline Alpine scrub & 101.7 & 6.6 & 25.8 & 10.6 & 127.5 & 7.1 \\
\hline Subalpine thicket & 150.5 & 9.8 & 3.6 & 1.5 & 154.1 & 8.6 \\
\hline $\begin{array}{l}\text { Subalpine fir } \\
\text { forest }\end{array}$ & 100.3 & 6.5 & 2.7 & 1.1 & 103.0 & 5.8 \\
\hline Temperate forest & 127.5 & 8.3 & 0.0 & 0.0 & 127.5 & 7.1 \\
\hline Bamboo thicket & 51.1 & 3.3 & 0.0 & 0.0 & 51.1 & 2.9 \\
\hline Temperate scrub & 5.9 & 0.4 & 0.0 & 0.0 & 5.9 & 0.3 \\
\hline Forest blank & 8.0 & 0.5 & 0.0 & 0.0 & 8.0 & 0.5 \\
\hline Total & 1540 & 100 & 244 & 100 & 1784 & 100 \\
\hline \multicolumn{7}{|c|}{ Table 1: Broad landcover types and their extent in KNP. } \\
\hline
\end{tabular}

\section{Results}

Analysis of the $30 \mathrm{~m}$ resolution Landsat ETM+ (2000) provided interesting results which are indicated below:

\section{Vegetation types and composition}

Greater Himalaya comprises $86 \%$ of the KNP landscape (southern and central parts), while the remaining $14 \%$ (northern part) is transHimalayan in character. The final classified image of the study area had 10 classes or landcover types (Table 1, Figure 3), of these, temperate forest constituted $11 \%$, subalpine forest $14 \%$, alpine forest $22 \%$ and a high proportion (53\%) of snow and rock. Amongst the vegetation classes, alpine meadows were the most extensive $\left(14.7 \%, 262 \mathrm{~km}^{2}\right)$, followed by temperate oak forests $\left(10 \%, 179 \mathrm{~km}^{2}\right)$ and subalpine thickets $\left(8.6 \%, 154 \mathrm{~km}^{2}\right)$

\section{Spectral separability and accuracy}

The average separability was 158 . Minimum class pair separability (25) was observed between subalpine thicket and alpine scrub followed by 37 between subalpine thicket and bamboo thicket (Table 2). 161 GPS points, in seven vegetation classes were used as a reference set for accuracy assessment. The confusion matrix generated had an overall

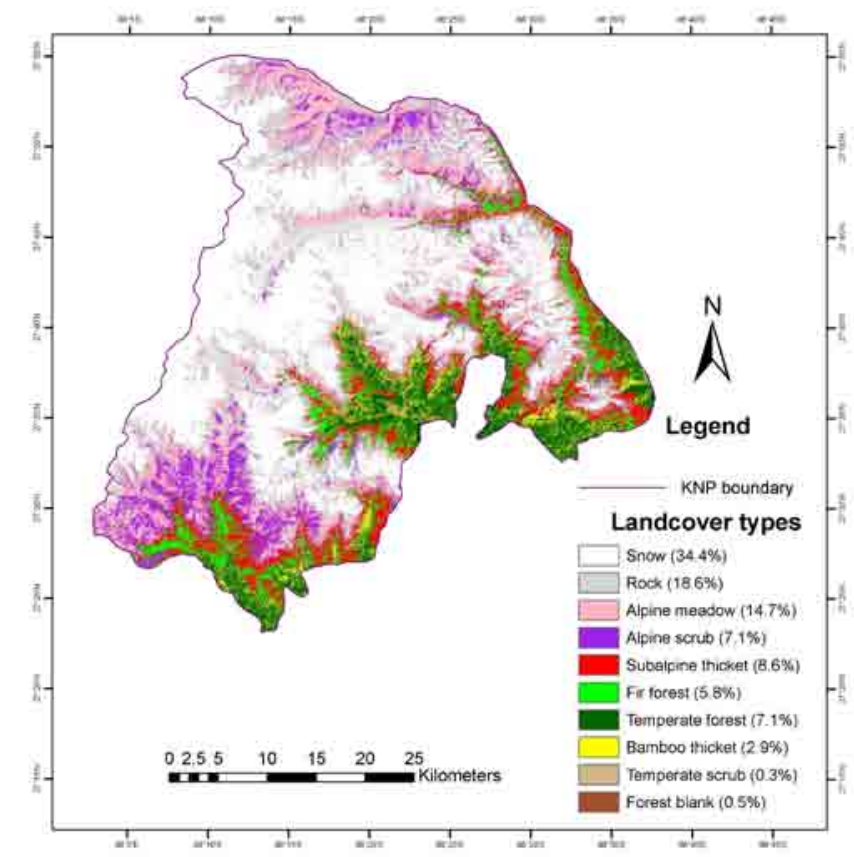

Figure 3: Landcover map of Khangchendzonga National Park, Sikkim Himalaya, India.

\begin{tabular}{|l|r|r|r|r|r|r|r|}
\hline & $\begin{array}{c}\text { Fir and } \\
\text { oak }\end{array}$ & $\begin{array}{c}\text { Bamboo } \\
\text { thicket }\end{array}$ & Rock & $\begin{array}{c}\text { Alpine } \\
\text { scrub }\end{array}$ & $\begin{array}{c}\text { Subalpine } \\
\text { thicket }\end{array}$ & $\begin{array}{c}\text { Alpine } \\
\text { meadow }\end{array}$ & Snow \\
\hline Fir and oak & $\mathrm{X}$ & 75 & 88 & 38 & 44 & 92 & 387 \\
\hline $\begin{array}{l}\text { Bamboo } \\
\text { thicket }\end{array}$ & & $\mathrm{X}$ & 74 & 61 & 37 & 58 & 355 \\
\hline Rock & & & $\mathrm{X}$ & 65 & 63 & 50 & 312 \\
\hline $\begin{array}{l}\text { Alpine scrub } \\
\text { Subalpine } \\
\text { thicket }\end{array}$ & & & & $\mathrm{X}$ & 25 & 57 & 375 \\
\hline $\begin{array}{l}\text { Alpine } \\
\text { meadow }\end{array}$ & & & & & $\mathrm{X}$ & 53 & 367 \\
\hline Snow & & & & & & $\mathrm{X}$ & 346 \\
\hline
\end{tabular}

Table 2: Spectral separability of the landcover classes across five bands in KNP. 
classification accuracy of $74 \%$. One drawback affecting the classification accuracy was that while the ground truth information was collected in summer the remotely sensed image was of winter. But, on correcting for the 12 ground truth points affected by snow cover, the overall classification accuracy improved to $81 \%$ with alpine scrub showing the lowest $(64 \%)$ and alpine meadow the highest (89\%) accuracy (Table 3). The mixing of the spectral signature of alpine scrub with alpine meadow and subalpine thickets in the transition zone results in its weak classification accuracy.

\section{Patch properties of the landscape}

The total vegetated area of KNP $\left(839 \mathrm{~km}^{2}, 47 \%\right)$ is composed of 70 790 patches with a mean patch size of 1.2 ha with large variation. The perimeter area ratio (mean) was 1173 and the shape index (mean) 1.3, suggesting relatively compact patches. The landscape configuration had the euclidean nearest neighbour distance of $85 \mathrm{~m}$, contagion was $39 \%$,

\begin{tabular}{|l|l|l|l|l|l|}
\hline Class Name & $\begin{array}{l}\text { Reference } \\
\text { Totals }\end{array}$ & $\begin{array}{l}\text { Classified } \\
\text { Totals }\end{array}$ & $\begin{array}{l}\text { Number } \\
\text { Correct }\end{array}$ & $\begin{array}{l}\text { Producers } \\
\text { Accuracy (\%) }\end{array}$ & $\begin{array}{c}\text { Users Accuracy } \\
\text { (\%) }\end{array}$ \\
\hline Snow & 11 & 11 & 11 & 100.00 & 100.00 \\
\hline Rock & 18 & 20 & 14 & 77.78 & 70.00 \\
\hline $\begin{array}{l}\text { Alpine } \\
\text { meadow }\end{array}$ & 68 & 63 & 56 & 82.35 & 88.89 \\
\hline Alpine scrub & 22 & 25 & 16 & 72.73 & 64.00 \\
\hline $\begin{array}{l}\text { Subalpine } \\
\text { thicket }\end{array}$ & 24 & 26 & 20 & 83.33 & 76.92 \\
\hline Fir forest & 10 & 8 & 7 & 70.00 & 87.50 \\
\hline Oak forest & 8 & 8 & 7 & 87.50 & 87.50 \\
\hline Total & 161 & 161 & 131 & & 81.37 \\
\hline
\end{tabular}

Table 3: Accuracy totals with winter snow correction in KNP.

\begin{tabular}{|c|c|c|c|c|}
\hline Category & Name & Symbol & Units & Value \\
\hline \multirow{14}{*}{$\begin{array}{l}\text { Landscape } \\
\text { composition }\end{array}$} & Total vegetated area & TA & $\mathrm{km}^{2}$ & 839 \\
\hline & Number of vegetated patches & NP & none & 70790 \\
\hline & Patch density of vegetated patches & PD & $\mathrm{km}^{2}$ & 84.37 \\
\hline & Patch area (mean) & AREA_MN & ha & 1.17 \\
\hline & Patch area (SD) & AREA_SD & ha & 27.63 \\
\hline & Effective mesh size & MESH & ha & 159 \\
\hline & Splitting index & SPLIT & none & 2128 \\
\hline & Patch richness & PR & none & 8 \\
\hline & Shannon's diversity index & SHDI & none & 1.75 \\
\hline & Simpson's diversity index & SIDI & none & 0.80 \\
\hline & Modified Simpson's diversity index & MSIDI & none & 1.63 \\
\hline & Shannon's evenness index & SHEI & none & 0.84 \\
\hline & Simpson's evenness index & SIEI & none & 0.92 \\
\hline & $\begin{array}{l}\text { Modified Simpson's evenness } \\
\text { index }\end{array}$ & MSIEI & none & 0.78 \\
\hline \multirow{5}{*}{$\begin{array}{l}\text { Landscape } \\
\text { shape }\end{array}$} & Perimeter area ratio (mean) & PARA_MN & none & 1173 \\
\hline & Perimeter area ratio (SD) & PARA_SD & none & 264 \\
\hline & Shape index (mean) & SHAPE_MN & none & 1.26 \\
\hline & Shape index (SD) & SHAPE_SD & none & 0.82 \\
\hline & Perimeter area fractal dimension & PAFRAC & none & 1.58 \\
\hline \multirow{5}{*}{$\begin{array}{l}\text { Landscape } \\
\text { configuration }\end{array}$} & $\begin{array}{l}\text { Euclidean nearest neighbour } \\
\text { distance (mean) }\end{array}$ & ENN_MN & meter & 85 \\
\hline & $\begin{array}{l}\text { Euclidean nearest neighbour } \\
\text { distance (SD) }\end{array}$ & ENN_SD & meter & 74 \\
\hline & Contagion & CONTAG & percent & 39 \\
\hline & Aggregation index & $\mathrm{Al}$ & percent & 65 \\
\hline & $\begin{array}{l}\text { Interspersion and juxtaposition } \\
\text { index }\end{array}$ & $|\mathrm{J}|$ & percent & 60 \\
\hline
\end{tabular}

Table 4: Selected landscape indices measuring landscape composition, shape and configuration of KNP. aggregation index was $65 \%$ and scattering at patch level as measured by interspersion and juxtaposition index was $60 \%$. The landscape diversity was 1.8 as per the Shannon's diversity index and the evenness as measured by the Shannon's evenness index was 0.8. Further details of landscape level metrices for KNP measuring landscape composition, shape, configuration and diversity is given in Table 4.

\section{Patch properties of classes}

The mean patch size for class metrics ranged from 0.8 ha (alpine scrub) to 12.2 ha (temperate forest) (Table 5). The alpine meadows had the largest number of patches and highest patch density $(\mathrm{NP}=21$ 471, $\mathrm{PD}=25.59)$ while the temperate forests were the most compact $(\mathrm{NP}=1030, \mathrm{PD}=1.23)$. Landscape fragmentation as measured by the mean patch area was highest for alpine scrub (AREA_MN=0.81) and fir forest (AREA_MN=0.91) and lowest for temperate forest (AREA_MN=12.24). Temperate forests exhibited a higher shape index compared to the other landscape classes. The disturbed vegetation classes namely forest blank and temperate scrub together comprise just $0.8 \%$ of KNP and generally had less number of patches, smaller patch size and lower patch density.

\section{Landscape characteristics of watersheds}

Amongst the seven major watersheds in KNP, Churong chu, Prek chu, Rangit chu, Lachen chu, Rangyong chu and Zemu chu showed characteristics of greater Himalaya i.e., higher relief ratio, more snow cover and extensive krummholz formations. Lhonak chu watershed in the extreme north exhibits rain shadow areas typical of trans-Himalaya. Also Churong chu, Prek chu and Lhonak chu watersheds have been strongly influenced by valley glaciers which have receded while the Zemu chu watershed is dominated by the $26 \mathrm{~km}$ long Zemu glacier. Rangyong chu and Rangit chu valleys do not show strong influences by valley glaciers. Only a minor part of the Lachen chu watershed falls within the KNP and hence is not fully representative, while the true left bank of the Lhonak chu watershed is outside the KNP. The relief characteristics of these watersheds show that the relief ratio is lowest for the trans-Himalayan glaciated valley of Lhonak $(R R=0.1)$, moderate for greater Himalayan glaciated valleys of Zemu, Prek and Churong $(R R=0.2)$ and highest for the greater Himalayan non-glaciated valleys of Rangyong and Rangit $(\mathrm{RR}=0.3)$.

The patch density of vegetated patches was lowest for the transHimalayan glaciated valley of Lhonak $(\mathrm{PD}=30.05)$, moderate for greater Himalayan glaciated valleys of Zemu, Prek and Churong (mean $\mathrm{PD}=37.09$ ) and highest for the greater Himalayan non-glaciated valleys of Rangyong and Rangit (mean $\mathrm{PD}=51.41$ ). The trans-Himalayan, glaciated valley of Lhonak showed lowerlandscape diversity (SHDI=0.85) and evenness (SHEI $=0.62$ ) compared to greater Himalayan valleys (mean SHDI $=1.58$, mean SHEI $=0.80$ ). Within the greater Himalaya, the glaciated valleys of Zemu chu, Prek chu and Churong chu showed lower landscape diversity (mean SHDI=1.42) and evenness (mean SHEI=0.78) as compared to the non-glaciated valleys of Rangit chu and Rangyong chu (mean SHDI=1.78, mean SHEI=0.86). The clumpiness is lowest and scattering highest in the Zemu $(\mathrm{CONTAG}=30.92, \mathrm{IJI}=89.59)$ and Rangyong watersheds $(\mathrm{CONTAG}=36.24, \mathrm{IJI}=61.37)$ with the Churong chu watershed $(\mathrm{CONTAG}=47.94, \mathrm{IJI}=44.54)$ being at the other end of the spectrum showing high clumpiness. The east-west orientation of the watershed results in dominant north south aspects which harbour different vegetation types, resulting in increased scattering. In northsouth oriented valleys the role of aspect is comparatively subdued that suppresses scattering. This east-west orientation of watershed is high in Rangyong and dominant in Zemu where one can observe different 
Citation: Sandeep T, Krishnamurthy R, Gopal SR (2012) Assessment of Landscape Characteristics and Changes in the Khangchendzonga National Park, Sikkim Himalaya, India. J Geophys Remote Sensing 1:10[ . doi:10.4172/2169-0049.100010]

Page 5 of 8

\begin{tabular}{|c|c|c|c|c|c|c|c|c|c|c|}
\hline \multicolumn{4}{|c|}{ Landscape indices at class level } & \multicolumn{5}{|c|}{ Natural vegetation classes } & \multicolumn{2}{|c|}{$\begin{array}{l}\text { Disturbed vegetation } \\
\text { classes }\end{array}$} \\
\hline Category & Name & Symbol & Units & $\begin{array}{l}\text { alpine } \\
\text { meadow }\end{array}$ & alpine scrub & $\begin{array}{l}\text { subalpine } \\
\text { thicket }\end{array}$ & fir forest & $\begin{array}{l}\text { temperate } \\
\text { forest }\end{array}$ & $\begin{array}{l}\text { temperate } \\
\text { scrub }\end{array}$ & forest blank \\
\hline \multirow{6}{*}{$\begin{array}{l}\text { Landscape } \\
\text { composition }\end{array}$} & Class area & $\mathrm{CA}$ & $\mathrm{km}^{2}$ & 262 & 127 & 154 & 103 & 179 & 6 & 8 \\
\hline & $\begin{array}{l}\text { Percentage of } \\
\text { KNP }\end{array}$ & PLAND & $\%$ & 14.7 & 7.1 & 8.6 & 5.8 & 10.00 & 0.30 & 0.50 \\
\hline & $\begin{array}{l}\text { Number of } \\
\text { patches }\end{array}$ & NP & none & 21471 & 15568 & 10582 & 11226 & 1030 & 2103 & 1636 \\
\hline & $\begin{array}{l}\text { Patch area } \\
\text { (mean) }\end{array}$ & AREA_MN & ha & 1.21 & 0.81 & 1.44 & 0.91 & 12.24 & 0.28 & 0.49 \\
\hline & $\begin{array}{l}\text { Patch area } \\
\text { (SD) }\end{array}$ & AREA_SD & ha & 24.82 & 13.17 & 24.99 & 11.30 & 170.12 & 0.76 & 1.57 \\
\hline & $\begin{array}{l}\text { Patch density } \\
\text { of vegetated } \\
\text { patches }\end{array}$ & PD & per $\mathrm{km}^{2}$ & 25.59 & 18.56 & 12.61 & 13.38 & 1.23 & 2.51 & 1.95 \\
\hline \multirow{2}{*}{$\begin{array}{l}\text { Landscape } \\
\text { shape }\end{array}$} & $\begin{array}{l}\text { Shape index } \\
\text { (mean) }\end{array}$ & SHAPE_MN & none & 1.27 & 1.23 & 1.27 & 1.25 & 1.47 & 1.16 & 1.23 \\
\hline & $\begin{array}{l}\text { Shape index } \\
\text { (SD) }\end{array}$ & SHAPE_SD & none & 0.73 & 0.72 & 1.05 & 0.72 & 2.20 & 0.39 & 0.46 \\
\hline
\end{tabular}

Table 5: Comparison of selected landscape indices measuring landscape composition and shape across different vegetation classes in KNP.

\begin{tabular}{|c|c|c|c|c|c|c|c|c|c|c|}
\hline \multicolumn{4}{|c|}{ Landscape indices } & \multicolumn{7}{|c|}{ Watershed name } \\
\hline Category & Name & Symbol & Unit & Lhonak & Rangyong & Rangit & Zemu & Prek & Churong & Lachen \\
\hline & Watershed characteristics & & & TH-G* & GH-NG* & GH-NG* & $\mathrm{GH}-\mathrm{G}^{*}$ & $\mathrm{GH}-\mathrm{G}^{*}$ & GH-G* & $\mathrm{GH}^{*}$ \\
\hline \multirow{13}{*}{$\begin{array}{l}\text { Landscape com- } \\
\text { position }\end{array}$} & Watershed area & $\mathrm{CA}$ & $\mathrm{km}^{2}$ & 243 & 664 & 118 & 368 & 144 & 152 & 95 \\
\hline & Percentage of KNP & PLAND & $\%$ & 14 & 37 & 7 & 21 & 8 & 9 & 5 \\
\hline & Highest elevation & HE & $\mathrm{m}$ & 7459 & 8476 & 5825 & 8586 & 6691 & 7338 & 5064 \\
\hline & Lowest elevation & LE & $\mathrm{m}$ & 3100 & 1220 & 2200 & 2700 & 2200 & 2200 & 1800 \\
\hline & Total relief & TR & $\mathrm{m}$ & 4359 & 7256 & 3625 & 5898 & 4491 & 5138 & 3264 \\
\hline & Basin length & $\mathrm{BL}$ & $\mathrm{m}$ & 44065 & 31413 & 10747 & 42697 & 25626 & 23953 & 27171 \\
\hline & Relief ratio & RR & none & 0.10 & 0.23 & 0.34 & 0.14 & 0.18 & 0.21 & 0.12 \\
\hline & Patch density of vegetated patches & PD & per km² & 30.05 & 44.44 & 58.39 & 26.98 & 45.99 & 38.31 & 54.93 \\
\hline & Patch area (mean) & AREA_MN & ha & 1.28 & 1.01 & 1.25 & 0.77 & 1.50 & 1.76 & 1.42 \\
\hline & Patch area (SD) & AREA_SD & ha & 31.63 & 29.99 & 17.19 & 10.84 & 27.71 & 28.29 & 25.49 \\
\hline & Patch richness & PR & none & 4 & 8 & 8 & 4 & 8 & 8 & 8 \\
\hline & Shannon's diversity index & SHDI & none & 0.85 & 1.81 & 1.76 & 1.17 & 1.68 & 1.42 & 1.62 \\
\hline & Shannon's evenness index & SHEI & none & 0.62 & 0.87 & 0.84 & 0.84 & 0.81 & 0.68 & 0.78 \\
\hline \multirow{4}{*}{$\begin{array}{l}\text { Landscape } \\
\text { shape }\end{array}$} & Shape index (mean) & SHAPE_MN & ha & 1.29 & 1.26 & 1.27 & 1.22 & 1.27 & 1.29 & 1.29 \\
\hline & Shape index (SD) & SHAPE_SD & ha & 0.77 & 0.77 & 0.92 & 0.62 & 0.92 & 0.94 & 0.93 \\
\hline & Landscape shape index & LSI & none & 11.84 & 42.62 & 32.24 & 11.36 & 30.18 & 26.93 & 24.52 \\
\hline & Perimeter area fractal dimension & PAFRAC & none & 1.58 & 1.58 & 1.59 & 1.57 & 1.58 & 1.56 & 1.60 \\
\hline \multirow[t]{5}{*}{$\begin{array}{l}\text { Landscape } \\
\text { configuration }\end{array}$} & $\begin{array}{l}\text { Euclidean nearest neighbour distance } \\
\text { (mean) }\end{array}$ & ENN_MN & meter & 82.51 & 85.14 & 82.56 & 93.92 & 82.60 & 83.17 & 80.69 \\
\hline & Euclidean nearest neighbour distance (SD) & ENN_SD & meter & 97.96 & 72.63 & 60.32 & 95.84 & 63.22 & 65.80 & 59.01 \\
\hline & Contagion & CONTAG & percent & 49.81 & 36.24 & 37.07 & 30.92 & 40.86 & 47.94 & 41.64 \\
\hline & Aggregation index & Al & percent & 67.60 & 62.29 & 63.38 & 60.63 & 67.66 & 69.64 & 66.01 \\
\hline & Interspersion and juxtaposition index & |J| & percent & 51.01 & 61.37 & 58.12 & 89.59 & 51.49 & 44.54 & 49.64 \\
\hline
\end{tabular}

${ }^{*} \mathrm{TH}=$ Trans Himalaya

$\mathrm{GH}=$ Greater Himalaya

$\mathrm{G}=$ Dominant valley glacier

NG $=$ No dominant valley glacier

Table 6: Comparison of selected landscape indices measuring landscape composition, shape and configuration of watersheds in KNP.

vegetation types on either flank of the valley resulting in higher mixing or dispersal and consequently lower clumpiness in the landscape. Lhonak also being east-west oriented however shows high clumpiness since only the northern aspect of the watershed falls within the study area, reducing the influence of aspect. The euclidean nearest neighbour distance (mean) and aggregation index also show similar trends. In the mountain watersheds of KNP while elevation gradient plays a major role in determining landscape composition, the landscape configuration is largely determined by the orientation. Rangyong watershed with a very high elevation gradient and a largely east-west orientation exhibits the highest overall landscape heterogeneity.

\section{Temporal change detection}

The geo-referenced Landsat time series data of $23^{\text {rd }}$ January, 1977 [24] and $26^{\text {th }}$ December, 2000 [25] were used for temporal change detection. Out of a total $1203 \mathrm{~km}^{2}$ of the park area below $5000 \mathrm{~m}$ elevation, $30 \mathrm{~km}^{2}(2.5 \%)$ was found to be impacted by a decrease of greater than $10 \%$ in NDVI values (Figure 4, Table 7). However, this 


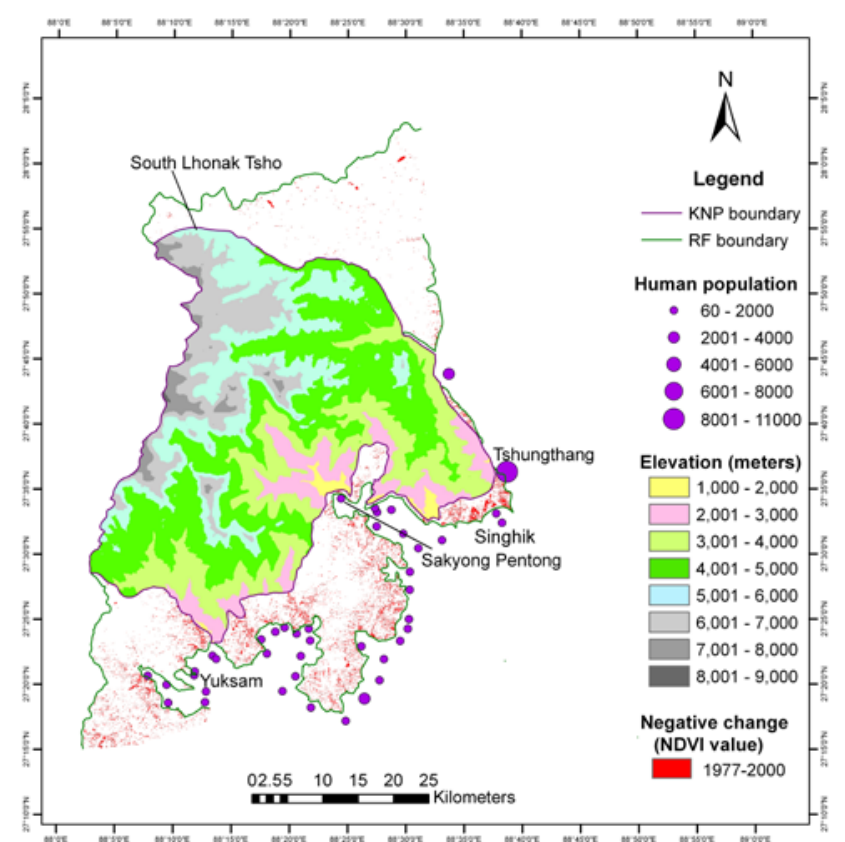

Figure 4: Distribution and extent of $>10 \%$ decrease in NDVI between 1997 and 2000 in and around Khangchendzonga National Park.

\begin{tabular}{|l|r|r|r|r|}
\hline & \multicolumn{3}{|c|}{ Altitudinal zones } & \multicolumn{1}{|l|}{ Total } \\
\hline & $\begin{array}{l}\text { Less than } \\
\mathbf{3 0 0 0}\end{array}$ & $\mathbf{3 0 0 0 - \mathbf { 3 8 0 0 m }}$ & $\mathbf{3 8 0 0 - \mathbf { 5 0 0 0 m }}$ & \\
\hline Total area of KNP & $194 \mathrm{~km}^{2}$ & $284 \mathrm{~km}^{2}$ & $726 \mathrm{~km}^{2}$ & $1203 \mathrm{~km}^{2}$ \\
\hline $\begin{array}{l}\text { Area impacted by great- } \\
\text { er than 10\% decrease } \\
\text { in NDVI }\end{array}$ & $14 \mathrm{~km}^{2}$ & $5 \mathrm{~km}^{2}$ & $11 \mathrm{~km}^{2}$ & $30 \mathrm{~km}^{2}$ \\
\hline $\begin{array}{l}\text { \% of total area impacted } \\
\text { by greater than 10\% } \\
\text { decrease in NDVI }\end{array}$ & 7.2 & 1.7 & & \\
\hline
\end{tabular}

Table 7: Extent of areas with more than 10\% decrease in NDVI between 1977 and 2000 in KNP.

change was not uniform. For instance, as much as $7.2 \%$ of the areas below $3000 \mathrm{~m}$ showed a decline in forest cover, while the vegetated areas in the subalpine and alpine zone showed only less than $2 \%$ change.

In the zone between 3000 to $5000 \mathrm{~m}$ the yak herders over the last 30 years have regularly set fire and burnt Juniper scrub in pockets at Lampokhri and Neer-pokhri Nikash converting the alpine scrub into grassy meadows, contributing to reduction in NDVI. A few alpine lakes such as South Lhonak Tsho in the trans-Himalaya show a substantial increase in size. In the subalpine zone the changes were mostly in the riverine areas possibly due to change in river course, glacial lake outburst floods or flash floods in the past. In the zone below $3000 \mathrm{~m}$ which showed largest areas impacted by negative change, substantial degradation was found close to the villages of Sakyong-Pentong, Singhik and Tshungthang in North Sikkim and Yuksam in West Sikkim. A large forest fire was reported from Payongchu ridge above Sakyong-Pentong in the spring of 1998, which could not be adequately contained due to the difficult terrain (T.B.Subba, personal communication, $18^{\text {th }}$ March 2007). Also portions of KNP close to human habitations showed greater negative change in vegetation compared to parts that were shielded by a buffer of reserve forest.

\section{Discussion}

High altitude protected areas such as KNP pose several challenges for the natural resource ecologists and managers in terms of understanding linkages between the landscape features and spatio-temporal changes caused by natural and anthropogenic factors. A substantial proportion of the Eastern Himalaya remains largely inaccessible for physical verification. Despite the advantages of remote sensing tools, reliefinduced factors limit utilization of potential of these tools [28]. Reflected signal values carry high variability and distortion by terrain complexity, shadow effects and cloud and snow cover. Persistent cloud cover during the summer months and snowfall in winter create only a small window of two-three months in early winter when the alpine zone can be adequately remotely sensed by satellites. Out of the 40 land cover classes segregated through unsupervised classification, 12 were of snow and ice, 11 were rock and glacier, 6 were shadow classes of vegetation and 11 non-shadow vegetation classes. The classified image was subset into contour intervals of less than $3000 \mathrm{~m}, 3000$ to $3800 \mathrm{~m}, 3800$ to $5000 \mathrm{~m}, 5000$ to $6000 \mathrm{~m}$ and greater than $6000 \mathrm{~m}$. For the shadow classes and oak and fir forests mixing, recoding was done to resolve this using elevation and ground truth information as a parameter. Mixing of subalpine thickets and temperate bamboo thickets was resolved by taking a buffer around the KNP to include more temperate forests. Extensive field surveys of vegetation structure and knowledge of altitudinal variation in major formations coupled with ground truthing proved necessary to enhance the accuracy of classification. The relative proportion of subalpine thickets (krummholz) and alpine scrub, which constitute suitable habitat for some of the endangered mammals including the Himalayan musk deer [29] was substantially higher as compared to the composition in the western Himalaya [30].

The landscape was found to be highly heterogeneous, with relatively compact patch shapes. This together with high values of aggregation, interspersion and diversity indices reflect rich landscape character, possibly not being heavily disturbed by unnatural forces. Disaggregating the landscape features of the KNP at watershed level was found to be very useful in identifying their character. Amongst the seven major watersheds, the Rangyong watershed, which covers $37 \%\left(664 \mathrm{~km}^{2}\right)$ of KNP was found to be most heterogeneous. The high landscape heterogeneity in this area could be related to a high relief ratio, east-west orientation, greater Himalayan character and not being dominantly impacted by valley glaciers.

In the change detection analysis, the variation in NDVI could arise from differences in spatial and spectral resolution of the sensors, differences in shadow intensity, variability of snow cover, variability in atmospheric conditions, changes in the vegetation density and noise [27]. The challenge was to significantly mask out the changes due to variations other than those emanating from changes in vegetation density. Inspite of taking into account atmospheric correction, a number of challenges were posed during the change detection analysis carried out on the Landsat images (year 1977, 2000). Though the spectral bands 2 and 4 of MSS and 3 and 4 of ETM+ sensors used to assess NDVI were spectrally similar and were taken less than a month apart, minor variations were found. The 2000 image had less snow cover in the alpine zone especially in the greater Himalayan part (south and centre) of KNP. Because of this reduction in winter snow cover, the alpine vegetation that was hidden under snow in the older image was visible in the new image, making the NDVI to show a positive bias in the snow covered areas. There was variation in the shadow intensity as well, with the 2000 image showing lighter shadows as compared to the 1977 image. Change detection in shadow areas was seriously hampered by variability in shadow intensity along with low spectral reflectance of vegetation. Hence all shadow areas were erroneously classified as a positive change (i.e. gain in vegetation cover) between the 1997 and 2000. To overcome 
Citation: Sandeep T, Krishnamurthy R, Gopal SR (2012) Assessment of Landscape Characteristics and Changes in the Khangchendzonga National Park, Sikkim Himalaya, India. J Geophys Remote Sensing 1:10[ . doi:10.4172/2169-0049.100010]

these challenges inferences from change detection analysis using NDVI were drawn only from the negative changes highlighted in the map, since the positive changes could be due to reduction in shadow intensity or decrease in snow cover between the two images. In order to determine the optimal threshold level, change detection was carried out at $10 \%, 15 \%$ and $20 \%$ levels of decrease in NDVI. Comparing this with the ground truthing information and digital photographs it was found that the $10 \%$ threshold value was the most accurate.

A total of 14 glacial lakes in the state have been identified as potentially dangerous [31]. In the KNP, a few alpine lakes like the South Lhonak Tsho in the trans-Himalaya show a substantial increase in size. In the late 1980's, two glacial lake outburst floods (GLOF) were reported in the Pagala pokhri and Tinkune pokhri in southern part of KNP [32]. In the summer of 2007, following incessant rains, flash floods in Zemu chu and Rangyong chu washed away bridges and consequently a few frontier villages were cutoff for weeks altogether. In the subalpine zone the changes were mostly in the riverine areas possibly due to flash floods or glacial lake outbursts in the past. In mountain terrain the riverine zone is preferred for development of communication and tourism infrastructure. Trekking foot-paths, trekker's huts, camping sites and other tourism facilities should be created at a safe distance from the river.

A national park as defined in the Wildlife Protection Act of India is closest to the IUCN Category $1 \mathrm{~b}$ - "Wilderness area" where the scope for meeting livelihood needs from activities other than tourism is limited [33]. In the KNP, a buffer of reserve forests around the park boundary helps in meeting the livelihoods needs of the people, thus shielding the park and reducing the chances of park people conflict. This could be related to the maximum degradation observed in the lower belt $(1000$ to $2500 \mathrm{~m}$ ) adjacent to the villages of Sakyong-Pentong, Singhik and Tshungthang in North Sikkim and Yuksam in West Sikkim and the buffer of reserve forests.

\section{Conclusion}

The challenges posed due to the hilly terrain, climate (cloud and snow cover), multi-layered vegetation structure and spectral characteristics of vegetation result in certain limitations in the accuracy of vegetation classification from remotely sensed satellite images in KNP. Though this results in certain uncertainty in the accuracy of vegetation classification, a hybrid approach using extensive field information in the form of ground truthing, digital photographs and knowledge about the spatial pattern of vegetation could improve the classification to acceptable limits for management purposes.

Remote sensing and GIS analysis provide useful insights in the conservation management of the KNP. Prioritizing conservation action to target the areas where maximum impacts have taken place will help in improving the effectiveness of conservation initiatives. Effective conservation of this landscape by forest staff alone is difficult due to its high altitude, remoteness, tough terrain, harsh climate and limited resources. The park management should consider enlisting the support of the villagers, practicing traditional subsistence livelihoods in this landscape, in conservation management. Also using watershed as a unit of management would be a practical approach to address their unique characteristics. Over the last three decades, possible impacts of climate change in the riverine zone and human pressure on the buffer and low-lying forests is visible. Buffer forests play a vital role in supporting the livelihood requirements of the local community and thus help in keeping the park inviolate. For the long-term security of this unique mountain landscape, the park management needs to evolve innovative co-management models, take adequate safeguards while using the riverine zone, strengthen buffer zone management and focus conservation measures in high impact areas.

\section{References}

1. Mulongoy KJ, Chape SP (2004) Protected Areas and Biodiversity: An overview of key issues. CBD, UNEP-WCMC, Cambridge, UK.

2. Hockings $M(2003)$ Systems for assessing the effectiveness of management in Protected Area. BioScience 53: 823-832.

3. Roy PS, Singh S, Dutt CBS, Jeganathan C, Jadav RN, et al. (1999) Biodiversity Characterization at Landscape level using Satellite Remote Sensing and Geographic Information System. DOS-DBT Users Manual, Indian Institute of Remote Sensing (NRSA), Dept. of Space, Govt. of India, Dehradun.

4. Singh TP, Singh S, Roy PS, Rao BSP (2002) Vegetation mapping and characterization in West Siang District of Arunachal Pradesh, India - a satellite remote sensing-based approach. Current science 83: 1221-1230.

5. Turner W, Spector S, Gardiner N, Fladeland M, Sterling E, et al. (2003) Remote Sensing for biodiversity science and conservation. Trends Ecol Evol 18: 306314

6. Quattrochi DA, Pelletier RE (1990) Remote sensing for analysis of landscapes: an introduction. In: Turner M.G. and Gardner R.H. (eds). Quantitative methods in landscape ecology: the analysis and interpretation of landscape heterogeneity. Ecological studies series, Springer-Verlag, New York

7. Groom G, Mucher CA, Ihse M, Wrbka T (2006) Remote sensing in landscape ecology: experience and perspectives in a European context. Landsc Ecol 21 391-408.

8. Roy PS, Tomar S (2000) Biodiversity characterization at landscape level using geospatial modelling technique. Biol Conserv 95: 95-109.

9. Kulkarni AV, Bahuguna IM, Rathore BP, Singh SK, Randhawa SS, et al. (2007) Glacial retreat in Himalaya using Indian Remote Sensing satellite data. Current Science 92: 69-74.

10. Blamont D, Méring C (1987) Use of remote sensing for vegetation and landuse mapping in mountainous areas: The case of central Nepal. Adv Space Res 7 : $41-46$

11. ISRO (1994) Forest Cover Mapping through Digital Image Processing of Indian Remote Sensing Satellite data with Special Reference of Sikkim - Procedura Manual and Inventory: Joint Collaboration Project of Forest Department Government of Sikkim and Regional Remote Sensing Service Centre, Kharagpur, Indian Space Research Organization, Department of Space, Government of India.

12. Ramachandra1 TV, Nagarathna AV (2002) Biodiversity Characterization at Landscape Level in North East India using Satellite Remote Sensing and Geographic Information System. Indian Institute of Remote Sensing, Department of Space, Government of India.

13. Kushwaha SPS, Padmanaban P, Kumar D, Roy PS (2005) Geospatia modelling of plant richness in Barsey Rhododendron Sanctuary in Sikkim Himalaya. Geocarto Int 20: 63-68.

14. Myers N, Mittermier RA, Mittermier CG, Da-Fonseca GAB, Kent J (2000) Biodiversity hotspots for conservation priorities. Nature 40: 853-858.

15. Mittermeier RA, Gil PR, Hoffman M, Pilgrim J, Brooks T (2004) Hotspots revisited: Earth's biologically richest and most endangered terrestrial ecoregions. CEMEX, USA.

16. Schaller GB (1977) Mountain monarchs: wild sheep and goat of the Himalaya. University of Chicago Press, Chicago, IL.

17. CISMHE (2005) Carrying capacity study of Tista basin in Sikkim. Volume Land Environment - Geophysical Environment. Centre for Inter-disciplinary Studies of Mountain and Hill Environment, University of Delhi, Delhi.

18. Champion HG, Seth SK (1968) A revised survey of the forest types of India Manager of Publications, Nasik, India.

19. Jarvis A, Reuter HI, Nelson A, Guevara E (2006) Hole-filled SRTM for the globe Version 3, CGIAR-CSI SRTM 90m Database. CGIAR Consortium for Spatial Information.

20. Census of India (2001) Provisional Population Totals: Paper 1 of 2001. Census of India, Gangtok. 
Citation: Sandeep T, Krishnamurthy R, Gopal SR (2012) Assessment of Landscape Characteristics and Changes in the Khangchendzonga National Park, Sikkim Himalaya, India. J Geophys Remote Sensing 1:10[ . doi:10.4172/2169-0049.100010]

Page 8 of 8

21. Mcgarigal K, Cushman SA, Neel MC, Ene E (2002) FRAGSTATS: Spatial Pattern Analysis Program for Categorical Maps. University of Massachusetts, Amherst.

22. NBSSLUP (2000) Sikkim soils prepared and published by National Bureau of Soil Survey and Land Use Planning (ICAR), Nagpur, Regional Centre, Calcutta, in cooperation with Department of Agriculture, Department of Forest, Government of Sikkim.

23. Schweinfurth U (1984) The Himalaya: Complexity of a mountain system manifested by its vegetation. Mt Res Dev 4: 339-344.

24. Nasa Landsat Program (1977) Landsat MSS scene p149r41_2m19770123, Orthorectified, GeoCover, USGS, Sioux Falls, 01/23/1977.

25. Nasa Landsat Program (2000) Landsat ETM+ scene p139r041_7t20001226, Orthorectified, GeoCover, USGS, Sioux Falls, 12/26/2000.

26. Chavez PS (1996) Image based atmospheric corrections- revisited and improved. Photogramm Eng Remote Sensing 62:1025-1036.

27. Lillesand TM, Kiefer RW (2000) Remote Sensing and Image Interpretation. 4th edition, John Wiley and Sons (ASIA) Pvt. Ltd, Singapore.
28. Buchrointhner MF (1995) Problems of mountain hazard mapping using spaceborne remote sensing techniques. Adv Space Res 15: 57-66.

29. Mcdonald D (2001) The new encyclopedia of mammals. Oxford University Press, New York.

30. Mathur VB, Naithani S (1999) Development of a Spatial Database of the Great Himalayan National Park Conservation Area (GHNPCA) in GIS Domain. Wildlife Institute of India, Dehra Dun, India.

31. Mool PK, Bajracharya SR (2003) Inventory of Glaciers and Glacial Lakes and Identification of Potential Glacial Lake Outburst Floods (GLOFs) Affected by Global Warming in the Mountains of Himalayan Region. Asia-Pacific Network for Global Change Research global change System for Analysis, Research and Training United Nations Environment Programme/Regional Resource Centre for Asia and the Pacific, International Centre for Integrated Mountain Development.

32. Tambe S, Chettri N, Gyalsten PG (2003) Rathong chu Valley, Sikkim Substate Biodiversity Strategy and Action Plan. NBSAP: Department of Forest Environment and Wildlife, Government of Sikkim, Gangtok, India.

33. Anonymous (2003) Wildlife (Protection) Act, 1972 (as amended upto 2003). Wildlife Trust of India, New Delhi, Natraj Publishers, Dehradun, India. 